\title{
The Impact of Collaborative Group Size on Students' Achievement and Product Quality in Project-Based Learning Environments
}

\author{
https://doi.org/10.3991/ijet.v15i10.12913 \\ Ensaf Nasser Al Mulhim ${ }^{(凶)}$, Amany Ahmed Eldokhny \\ King Faisal University, Al-Ahsa, Saudi Arabia \\ ealmulhimekfu.edu.sa
}

\begin{abstract}
This paper focuses on comparing collaborative group sizes (small versus large) in terms of developing preservice teachers' skills in designing webpages using HTML in a project-based learning environment. It examines the effect that group size has on academic achievement and product quality in project-based learning environments. The experiment involved 74 undergraduate students enrolled in the sixth level of the Computer Teacher Program, Faculty of Education, King Faisal University in Saudi Arabia, during the second term of the school year 2018-2019. Study results indicate that there are significant differences between large and small size groups as they relate to students' academic achievement and product quality, showing a preference for a large group, which disagrees with most of the existing literature. In this study, the researchers explain this disagreement and recommend new directions in researching group sizes in project-based learning environments in the future.
\end{abstract}

Keywords-Blended learning, preservice teachers, webpage design, small-size group, large-size group, King Faisal University, Saudi Arabia

\section{Introduction}

Project-based learning is a teaching and learning strategy that involves learners in rich learning situations to accomplish a certain goal collaboratively over a period of time [17] [10]. It has been broadly employed in different education fields, especially in science, mathematics, computer science, social science, and technology [17] [28] [32] [51]. The literature has cited numerous benefits of project-based learning in education, such as improving attitudes towards learning, improving motivation and academic achievement, emphasizing self-assessment, supporting self-directed learning, developing self-regulation skills, enhancing practical thinking and problem solving skills, and encouraging collaboration [10] [17] [24] [42].

As project-based learning heavily depends on groups of students working together to achieve certain goals, the size of these groups has been an important issue to investigate. There is a debate in the literature about the most appropriate group size for project-based learning strategies [2] [3] [14] [44] [37]. Some studies showed that a 
small group outperforms a large group. For example, Shaw [53] recommended designing instruction with small groups to support more effective student-centered discussions and encourage high levels of student participation to increase learning performance. The interaction between students in small groups is seen as more effective and it promotes a high sense of community [4]. Large group size was determined as more effective when used in online brainstorming [1] [20] [38] [48] and online discussions [3].

On other hand, some studies found no significant effect of group size on students' performance or results [14] [25] [57]. The previous reviews do not determine the most suitable group size for better outcomes. Therefore, the present study will compare small and large group sizes in terms of students' achievement and product quality using project-based learning strategies.

\section{$2 \quad$ Literature Review}

\subsection{Collaborative group size}

Collaborative learning groups involve bringing students into smaller group sizes to enhance engagement [37]. Essentially, strategic planning is critical to the development of effective collaborative groups. Brame and Biel [12] define a collaborative learning group as "the use of small groups as a form of instruction from where student's learning is enhanced by promoting their abilities to learn from one another." Collaborative learning is used extensively in learning institutions to promote knowledge transfer.

Collaborative learning group size is based on the social interdependence theories of Kurt Lewin [40] and Morton Deutsch [22], which assert social interdependence has a positive impact on social interactions, which consequently leads to positive outcomes among students. Social interdependence "exists when the accomplishment of each individual's goal is affected by the actions of others" [33] (p. 11). According to Johnson and Johnson [33] social interdependence plays a crucial role in establishing a group structure that enhances group members working together, building quality relationships, and interactively supporting each other's learning. They believed that successful group experience would lead to greater effort from the group members to achieve their goals. So, individuals perceive that their goals are only achievable if the other members of the group achieve their goal as well, which leads to promoting one another's efforts. The interdependence theory maintains that group work is critical and there are significant higher performances with groups of any size compared to the individualistic competition. However, outcomes can be enhanced with the utilisation of smaller group sizes. Kooloos et al. [37] and Panadero and Jarvela [45] confirm the importance of smaller group sizes and maintain they are critical in enhancing participation of individuals in the peer teaching processes, which consequently enhances learning.

Further, Blatchford and Russell [11] stated that large groups, as in the case for higher classroom sizes, are less effective, because they hamper management and 
contribute to higher challenges for instructors. Smaller groups make management easy and improve the performance of the students extensively. Smaller groups increase opportunities for all students, enhance their participation, and consequently contribute to better performances.

Instructors usually incorporate collaborative learning groups in teaching for various reasons, including skill development and increasing students' understanding. According to Brame and Biel [12], instructors often use smaller groups to maximise the benefits of peer-to-peer learning. Collaborative learning groups are fundamental to instruction as they promote positive interdependence where an individual's good performance contributes to the success of the entire group. Further, Curşeu, Schruijer and Fodor [21] believed that collaborative learning allowed student groups to develop shared learning through engagement in collective educational activities.

Collaborative learning group sizes are critical to influencing student performance and improve achievement. Melero, Hernández-Leo, and Manatunga [44] found that the size of a group (4 versus 5) played a key role in students' engagement and their activity performance. According to Kooloos et al. [37], students usually preferred learning in small groups of 5 students, and sessions that allowed for peer teaching to a large group of 15 students.

Importantly, the teaching format is critical, as it creates a perception of higher learning gain and allows students to achieve their goals while encouraging active participation. When students have access to their preferred method of instruction, they show a higher ability to retain the knowledge gained. Small group sessions are also critical for online educational platforms. Therefore, group size plays a significant role in improving achievement, self-esteem, and providence of social support for students, which consequently contributes to better performance. Similarly, Sung et al. [57] found that group size using a mobile-computer supported collaborative learning (MCSCL) did not affect the performance of the group, as opposed to findings by a majority of researchers. However, the authors note the value of comment sections, mobile app products, discussion processes, unlimited distance, and real-time display, in enhancing student participation in terms of effectiveness and efficiency. Further, larger groups are critical, as they increase mutual feedback and diverse viewpoints critical to learning, motivation, and enhanced performance.

Social support, according to Curşeu, Schruijer, and Fodor [21], creates a positive association between knowledge elaboration and minority dissent among groups. Particularly, social integration and the management of the complexity of groups are critical and it is easier in small groups, and they create favourable conditions for learning. Further, Curşeu, Schruijer and Fodor [21] found a positive relationship between collaborative learning with group cognitive complexity; however, the relationship reaches a plateau at five to six members, wherein negative results are then obtained. The findings are critical to informing instructors about the optimum size of a collaborative learning group that will capitalize on the student benefits.

Khong, Liem and Klassen [35] maintain that small groups are effective instructional strategies because they enhance task accomplishment and performance. Further, findings from the study show that collective efficacy, and not self-efficacy was a more fundamental factor in the performance of a group. For this reason, while 
small group sizes are critical to enhancing performance, they call for all students to participate extensively. Further, the ultimate results in student learning can be attained when groups are developed in such a way as to reduce heterogeneity as such aspects increase misunderstandings and ultimately reduce collaboration.

In summary, collaborative group learning is fundamental to improving student performance in a classroom setting as opposed to individual learning efforts. While most studies advocate for smaller groups, as they are more effective, online platforms show the significance of incorporating larger groups. Overall, collaborative learning groups, of any size are more beneficial compared to individual efforts alone. However, the literature does not define the most appropriate number of students in either the small- or the large-sized groups. Therefore, the present study proposes the small group size to be from 3 to 4 members and the large group size to be from 7 to 8 members.

\subsection{Project based learning}

Project-based learning is an educational tool used to engage students to develop skills and acquire knowledge. Chen and Yang [17] defined project-based learning as systematic methods of teaching and learning that give students opportunities to learn from the real world through presentations. Similarly, Biasutti and El-Deghaidy [9] provided that project-based learning was an educational technique to enhance learning through problem-solving activities. Project-based learning, as opposed to the traditional method of learning, enables learners to acquire knowledge through individual or group projects [5] [16] [49]. Ultimately, project-based learning ensures knowledge acquisition by fully engaging students in the construction of knowledge through interactions with peers and the environment.

Project-based learning is based on the theory that problem-solving group activities improve the learning environment, knowledge attainment, and student performance. Project-based learning recognizes the importance of collaborative learning and, thus, requires the grouping of students. According to Paschalis [47], collaborative strategies in project-based learning motivate and make students active in the learning process. Further, collaborative instructional methods are based on the theory that it requires instructors to flexibly intervene and guide students to make the most out of their learning.

Similarly, the project-based learning model has been determined to be effective in achieving cognitive, affective, and psychomotor learning outcomes [58]. Moreover, Baser, Ozden, and Karaarslan [8] find that collaborative project-based learning exposes students to practices that enhance collaborative and technological skills. Seman, Hausmann, and Bezerra [52] conducted an experiment on web-based learning that incorporated project-based learning strategies, and found that the approaches of knowledge acquisition are based on cooperation and ego. The humanization aspects form the basis of learning and are an important part of education for students. Therefore, project-based learning increases student engagement in problem-solving activities. The activities are essential gateways for acquiring knowledge through the application, as well as building skills. 
Project-based learning is critical to learning as it allows the students to gain a deeper understanding of standards and concepts based on the activities engaged. In an experiment, Chen and Yang [17] found that project-based learning had between an average to a higher positive effect on the achievements of students compared to traditional teaching methods. Knowledge acquisition and group activities are essential to motivating students and inspiring commitment and ambition to attain higher levels of performances. According to Hugerat [29], project-based learning improved the climate in a classroom environment characterized by positive teacher-student relations, higher teacher supportiveness, enjoyableness, and improved relationships. Ultimately, the improved perception and learning environment contributes to positive student achievements and higher performances [19].

Even though there are significant benefits to using project-based learning techniques, there are also challenges with the implementation of the new curriculum [50]. Therefore, it is prudent to extensively involve teachers' perception to identify the measures that will promote successful implementation and minimize possible negative impacts. Further, Iwamoto, Hargis, and Vuong [31] did a two-step experiment on psychology students and found that students in the experimental and control groups had negative attitudes towards project-based learning when initially introduced. However, the second experiment showed that self-disciplined students in the experimental group had higher academic performance. Therefore, strategies are needed to introduce students to project-based learning techniques.

Group activities are critical in project-based learning. According to Splichal, Oshima, and Oshima [55], collaboration is a key practice to enhance success in learning in the twenty-first century. This, then, begs the question as to an ultimate group size that will ensure a positive outcome on student performance. According to Lin and Tsai [41] and Chen and Yang [17], the size of the group in project-based learning does not affect the outcome of learning. Contrary, Chou and Chang [18] found that a smaller group size comprised of four or fewer students improved satisfaction in design skill development for engineering students. Higher satisfaction was associated with high skill development, higher performances, and higher problem-solving abilities.

\subsection{Academic achievement}

There is some literature that examined the influence of students' group size on their achievement. For instance, Enu et al. [25] conducted an investigation of the influence of group sizes of 3, 4 and 5 students on their achievements. The analysis of the data reported no significant differences between the different group sizes in terms of the students' achievement. According to Akcaoglu and Lee [4], small groups in on online platforms showed significant results in improving social presence, which consequently leads to improved student achievement. Also, Manathunga and Hernández-Leo [43] stated that online platforms that incorporated massive interaction of students realised benefits in terms of improved student performances. Therefore, there are both real and perceived benefits of collaborative group learning that, in turn, contribute to positive student learning and improved achievements. 
Regarding the subject of group size, much of the research suggested that a projectbased learning environment can improve students' academic achievement [7] [10] [26] [34] [42] [54] [56]. For example, Bilgin et al. (2015) carried out a study that investigated the effect of project-based learning on students' achievement and selfefficacy beliefs in a science-teaching course in the Primary School Education Department of a State University in Turkey. The findings of this study revealed significant differences between the experimental and control groups in term of academic achievement in favour of the experimental group. A similar study was conducted by Mahasneh and Alwan [42] to examine the effect of project-based learning on the achievement and self-efficacy of student teachers at the Faculty of Educational Science at the Hashemite University of Jordan. They concluded that the experimental group a higher level of achievement than the control group. The researcher also found that project-based learning could improve student teachers' classroom management, engagement, and efficacy.

Summers and Dickinson [56] carried out a longitudinal study to explore the effect of project-based learning on high school social studies students' academic achievement and college and career readiness. The participants of both the control and the experimental groups were from the same rural school district in the United States. The findings from the achievement assessment showed that the experimental group outperformed the control group in terms of academic achievement in social studies. On the other hand, there are some studies that disagree with the previous findings, and that believe project-based learning does not influence students' achievement [6] [15] [27] [59].

The majority of the literature confirmed that project-based learning plays a crucial role in improving students' achievement. It suggested, moreover, that group size had an effect on students' achievement in favour of a small-sized group. Notably, the literature mostly has explored project-based learning and students' group size separately. However, there is a lack of studies that examine the effect of both variables with regard to student's learning outcomes, such as achievement, motivation, self-efficacy, and attitudes toward learning. This study will, therefore, cover some of this area of shortage.

\subsection{Product quality}

Product quality refers to the extent to which a product meets the design standards [30]. The literature shows that working in groups may enhance the quality of a product by reducing individual working load and time as well as sharing extensive focused feedback within the group [15] [18] [39]. This, as a result, leads to the assumption that having more feedback and points of view within a group may improve product quality. The literature does indicate that large group size can produce more mature and meaningful feedback [20] [23] [46] [48]. However, the literature does not clearly examine the effect of project-based learning group size on the quality of a product. The present study emphasizes this variable to a greater degree. 


\section{$3 \quad$ Research Questions and Hypotheses}

\subsection{Questions}

1. Does collaborative group size (large versus small) in project-based learning environments have an impact on students' academic achievement?

2. Does collaborative group size (large versus small) in project-based learning environments have an impact on students' product quality?

\subsection{Hypotheses}

Hypothesis One: There are significant differences between large collaborative group size and small collaborative group size in project-based learning environments in terms of impact on academic achievement at level (0.05) in favour of a small group size.

Hypothesis Two: There are significant differences between large collaborative group size and small collaborative group size in project-based learning environments in terms of impact on product quality at level $(0.05)$ in favour of a small group size.

\section{$4 \quad$ Methodology}

\subsection{Study approach}

The present study employed the experimental approach to determine the impact of the collaborative group's size (small versus large) in project-based learning environments on students' academic achievement and product quality.

\subsection{Participant population}

The participants were 74 students enrolled in an undergraduate course, namely "Web Pages Design Tools," in the College of Education at King Faisal University, Saudi Arabia. The students were randomly divided into large- and small-sized groups. There were 11 small-sized groups of 3 to 4 students each, and 5 large-sized groups of 7 to 8 students each.

\subsection{Research design}

The researchers utilized the Analysis, Design, Development, Implementation and Evaluation model (ADDIE) by Branch [13].

Analysis stage: The main objective of this study was to define the best collaborative group size (small versus large) as it applies to project-based learning environments to be used in designing web pages. Likewise, participants' characteristics with regard to age, education, and needs were defined. The participants 
were sixth-level students enrolled in the "Web Pages Design Tools" course at the Computer Teacher Program at King Faisal University, Saudi Arabia. The participants were unfamiliar with the educational content that was to be learned, but possessed the basic skills needed to work with computers, the Internet, and programming in general. The educational environment required the computers to be connected to the Internet and equipped with HTML language.

Design stage: The study adopted a project-based learning strategy. The project's main goal was to equip students with the skills needed to create a Curriculum Vita (CV), in the form of a webpage, using HTML. The behavioural objectives of the "Web Pages Design Tools" course were defined. An initial list of objectives was assessed by experts in the field of educational technology for approval. They found the list to be $96 \%$ valid and suggested some modifications. The final list of the objectives included the experts' suggested modifications.

Essential knowledge and skills areas to be learned through the project activities were identified. There were six primary skills of webpage design that students needed to learn as shown in Figure 1.

Development stage: In this stage, the learning content that was "Web Page Design Skills" was made available on the learning management system (Blackboard) to be taught during 14 weeks. Learning resources, including but not limited to presentations, links to websites, and links to YouTube videos, were made available to students via the Blackboard. The project's main task, to design a CV on a web page using HTML, was created on a Blackboard page. A discussion forum was created for each group of the sample on Blackboard to facilitate online communication. LAN was put into operation in the computer labs.

Implementation stage: A pilot study was conducted using 10 students who possessed the same demographic characteristics of the main study sample. The researchers ascertained that prior knowledge of the learning content was lacking. The sample was divided into one large group of six and one small group of four. The experiment was applied to verify the clarity of the project, as well as the validity and the reliability of the study's instruments. The pilot study was also important to identify any barriers that might prohibit the conducting of the main experiment. 


\begin{tabular}{|c|c|c|}
\hline Main Skills & Sub-Skills & Performance Skills \\
\hline \multirow{19}{*}{ 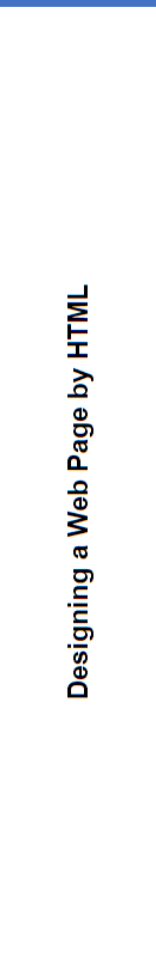 } & \multirow{9}{*}{$\begin{array}{l}\text { 1. Adding } \\
\text { Items and } \\
\text { Texts }\end{array}$} & Bold black underlined for a Web Design sentence. \\
\hline & & $\begin{array}{l}\text { Use }<b r>\text { to insert a space line between the lines of } \\
\text { a paragraph. }\end{array}$ \\
\hline & & $\begin{array}{l}\text { Use }<\text { Maxlength }>\text { to identify the maximum number of } \\
\text { letters that can be entered into data fields. }\end{array}$ \\
\hline & & Use style code to link pages with HTML language. \\
\hline & & $\begin{array}{l}\text { Make the head of the paragraph orange and align } \\
\text { the text to centre, applied to all the heads in under } \\
\text { the code. }\end{array}$ \\
\hline & & Use different sizes for tag $\mathrm{h}$ (head of paragraphs) \\
\hline & & Use double or single quotation marks. \\
\hline & & Examine the values of property dir :RTL 'LTR. \\
\hline & & Put a heading for the web page using tag head. \\
\hline & \multirow{2}{*}{$\begin{array}{l}\text { 2. Adding } \\
\text { Pictures and } \\
\text { Paints }\end{array}$} & $\begin{array}{l}\text { Use property }<\mathrm{SRC}>\text { to create a caption under a } \\
\text { picture. }\end{array}$ \\
\hline & & $\begin{array}{l}\text { Use tag <alt> in describing a picture in case it does } \\
\text { not appear in the browser. }\end{array}$ \\
\hline & \multirow{2}{*}{$\begin{array}{l}\text { 3. Adding } \\
\text { Colours and } \\
\text { Backgrounds }\end{array}$} & $\begin{array}{l}\text { Identify the colour value of the web page through the } \\
\text { sixteenth system. }\end{array}$ \\
\hline & & $\begin{array}{l}\text { Use tags }<\text { bgcolor }>\text { to change the colour of the web } \\
\text { page. }\end{array}$ \\
\hline & \multirow{2}{*}{$\begin{array}{l}\text { 4. Adding } \\
\text { Hyperlinks }\end{array}$} & Use tags $<\mathrm{href}>$ to link the web page on the website. \\
\hline & & $\begin{array}{l}\text { Use tags <href..target blank }>\text { to make a hyperlink } \\
\text { that opens in a new page. }\end{array}$ \\
\hline & \multirow{2}{*}{$\begin{array}{l}\text { 5. Adding } \\
\text { Frames and } \\
\text { Lists }\end{array}$} & Use tags $<O L>$ to make an ordered list. \\
\hline & & Use tag $<U L>$ to make an unordered list. \\
\hline & \multirow{2}{*}{$\begin{array}{l}\text { 6. Adding } \\
\text { Timetables }\end{array}$} & Use tags $T d$ to create a timetable. \\
\hline & & Use tags $<$ tr $>$ to create a timetable row. \\
\hline
\end{tabular}

Fig. 1. Skills to be learned through the project's activities

Evaluation stage: This stage involved the formative evaluation of all of the previous stages, including the design and the implementation of the treatment. The feedback from the pilot study was considered and essential amendments were made to prepare the final form of the treatment.

\subsection{Data collection instruments}

Academic achievement test: A closed-ended test was prepared to measure students' achievement of the skills related to the subject of Webpage design tools (shown in Figure 1). The test consisted of 30 multiple-choice questions scoring 1 point per question. The total score on the test was 30 points.

The validity of the achievement test was calculated by the review of a group of judges in the field of instructional technology. They provided feedback on its coverage of the educational goals, its relevance to the content, and the relevance and precision of the test items. The judges unanimously agreed to grant the test about $92 \%$. There were some recommendations on the wording of some items. The 
amendments were made and the test became ready for the participants of the pilot experiment to enable the authors to calculate the statistical validity of the test.

The reliability of the test was calculated by testing and retesting a pilot sample of 10 students over a period of two weeks. The reliability coefficient was (0.82), an acceptable value for test reliability. The average response time for the test was calculated at 51 minutes.

Product quality card: To assess the quality of the CV webpage design, a product evaluation card was created. The evaluation card had three main axis for a total of 21 items to be assessed on a five-point Likert scale (Novice $=1$; Emerging $=2$; Developing $=3$; Proficient $=4$; Expert $=5$ ). The card scores ranged from 21 to 105 points. The total score of the card reflected the product quality.

The validity of the product evaluation card was judged by a group of experts in the field of educational technology. The results revealed some recommendations of rephrasing of some of the items for more clarification. There was a good consensus of the card's validity in general. Similar to the achievement test, the reliability of the product quality evaluation card was calculated from the data gathered from the pilot experiment, using Spearman's coefficient. The score of 0.91 indicated a highly significant reliability.

\subsection{Procedure}

An introductory meeting was held with the participants to improve their responsibility and motivate them to satisfactorily accomplish the learning outcomes. They were introduced to the project's main aim and behavioural objectives. The main task, i.e. designing a CV webpage using HTML, was explained. The participants were made aware of the webpage design skills that they needed to develop to successfully complete the project.

As aforementioned, participants were divided into 11 small-sized groups of 3 to 4 students each ( 7 groups of 3 and 4 groups of 4), and 5 large-sized groups of 7 to 8 students each ( 3 groups of 7 and 2 groups of 8 ).

The academic achievement pre-test was applied to both small and large groups to ensure their equivalence and to calculate their achievement scores. A discussion forum for each group was set up on Blackboard. The participants were also introduced to the available learning resources on Blackboard.

Both small and large groups started to communicate via the discussion forums to define their sub-tasks and organize how they would accomplish them. Both researchers were available to help and scaffold the students when needed, and to facilitate any difficulties that they may face.

The assessment, using the academic achievement post-test and the product quality card, were carried out once the experiment was completed.

The main experiment took place over 14 weeks during the second term, from the 6th of January until the 25th of April 2019.

The data from both the achievement test and the product quality evaluation card was processed and statistically analysed to test the hypotheses, using independent 
sample t-tests to examine the differences between the average scores of the two experimental groups (small versus large).

\section{$5 \quad$ Results and Discussion}

Statistical analysis software SPSS 22 was used for the analysis of the data. In order to identify the impact of the collaborative groups' size on students' achievement and product quality, independent sample t-tests were used.

\subsection{Homogeneity between experimental groups}

Table 1 shows the independent sample t-test for the research groups' average scores and standard deviation of achievement pre-test. The data showed that there was no significant differences between small size group $(\mathrm{M}=5.08 ; \mathrm{SD}=1.89)$ and large size group $(\mathrm{M}=4.57 ; \mathrm{SD}=1.52)$ in the achievement pre-test $(\mathrm{t}=1.29 ; \mathrm{p}>0.05)$, thus the two groups were homogeneous before conducting the experiment.

Table 1. Independent t-test for the research groups on the achievement (pre-test)

\begin{tabular}{|l|c|c|c|c|c|c|}
\hline \multicolumn{1}{|c|}{ Group Size } & N & Mean & SD & Df & t & Sig. \\
\cline { 1 - 5 } Small & 37 & 5.08 & 1.89 & \multirow{2}{*}{72} & \multirow{2}{*}{1.29} & .202 \\
\hline Large & 37 & 4.57 & 1.52 & & & \\
\hline
\end{tabular}

\subsection{Academic achievement}

Table 2 shows the independent sample t-test for the research groups' average scores and standard deviation of achievement post-test. The data showed that there were significant differences between small size group $(\mathrm{M}=24.41 ; \mathrm{SD}=3.23)$ and large size group $(\mathrm{M}=27.51 ; \mathrm{SD}=1.12)$ in the achievement post-test $(\mathrm{p}<0.05)$ in favour of the large group. Thus, the first hypothesis was rejected.

Table 2. Independent t-test for the research groups on the achievement (post-test)

\begin{tabular}{|l|c|c|c|c|c|c|}
\hline \multicolumn{1}{|c|}{ Group Size } & N & Mean & SD & Df & t & Sig. \\
\cline { 1 - 4 } Small & 37 & 24.41 & 3.23 & \multirow{2}{*}{72} & \multirow{2}{*}{5.51} & .000 \\
\hline Large & 37 & 27.51 & 1.12 & & \\
\hline
\end{tabular}

\subsection{Product quality}

Table 3 shows the independent sample t-test for the research groups' average scores and standard deviation of product quality post-test. The data showed that there were significant differences between small size group $(\mathrm{M}=82.86 ; \mathrm{SD}=8.46)$ and large size group $(\mathrm{M}=90.89 ; \mathrm{SD}=10.39)$ in the product quality card post-test $(\mathrm{p}<0.05)$ in favour of the large size group. Thus, the second hypothesis was rejected. 
Table 3. Independent t-test for the research groups on the product quality

\begin{tabular}{|l|c|c|c|c|c|c|}
\hline \multicolumn{1}{|c|}{ Group Size } & N & Mean & SD & Df & t & Sig. \\
\hline Small & 37 & 82.86 & 8.46 & \multirow{2}{*}{72} & \multirow{2}{*}{3.64} & .001 \\
\hline Large & 37 & 90.89 & 10.39 & & & \\
\hline
\end{tabular}

Regarding the data shown Tables 1 and 2, it was revealed that both experimental groups did well in the achievement test, and their final products were good in general. This can confirm that the collaborative project-based learning environment was effective for the students, as stated by most of the literature [7] [8] [10] [26] [34] [42] [47] [54] [56] [58]. However, the result of the current study showed that the large size groups were more effective in terms of students' achievement and product quality. This may be explained by that fact that the students are usually assigned to large groups whenever they work on projects. They are familiar with learning and interacting in project-based learning environments in large groups, which improve their engagement in their learning experiences and motivates them to accomplish project goals. This, as a result, improves their achievement and the quality of their product. The studies of Parks-Stamm, Zafonte, and Palenque [46]; El-Said and ElEmam Rabea [23]; Paulus, Kohn, Arditti, and Korde [48]; and Coskun [20] support that working in large groups increases communication skills, participation, interaction, development of meaningful feedback among students of the group, and improves product quality.

The results of this study disagreed with the majority of the reviewed literature that favoured small-sized groups to improve learning outcomes. However, the results are supported by social interdependence theory that advocates that the goal of each member in a group is only achievable when other members achieve their goals. The more students in the group, the more learners collaborate, engage, interact and put forth efforts in the project environment to achieve the project goal, which may lead to better learning outcomes.

Despite that there is not much literature that supports the effect of large-sized group versus small-sized group on students' academic outcomes, it has been found that most of the literature that examines the effect of group size on different variables did not consider the same exact number of members in each type of group (large or small) [3] [14] [20] [23] [37] [44]. In these studies, the number of students in the small groups ranged from 3 to 9 . The number of students in the large-sized groups was 5 to 30 . Other studies divided groups into small, medium, and large sizes, with a different number of members in each. This suggests that the best size for both small and large groups is still not yet clearly determined.

\section{Conclusion}

This study's goal was to discover the best collaborative group size of students working in a project-based learning environment. The study compared large-sized groups of 7 to 8 students and small-sized groups of 3 to 4 students in terms of their 
achievement and the quality of their final product. The results were significantly in favour of large-sized groups.

The study is believed to contribute to the field by helping teachers to choose the most suitable collaborative group size when designing their teaching methods and goals in project-based learning environments.

Deciding on the most appropriate group size appears to be related to many factors that support the success of the group size, such as the examined variables and the learning environment. Some studies that investigate students' performance in discussion forums emphasized the importance of having groups of eight members or more. The large number here is assumed to enhance student interaction, motivate more participation, provide greater mutual feedback [46], and improve product quality [23]. On the other hand, small group size was favoured when studies examined critical thinking skills, student performance, language learning skills, and online discussion participation and skills [3] [14] [36] [53].

Therefore, the debate on the best group size in project-based learning has not been finalized yet and still needs further investigation. More studies that investigate the effect of group size with a fixed number of students are needed to determine the most appropriate number of members in each group size (small, medium, and large).

This study also suggests further research on group size in project-based learning environments and other dependent variables, such as learning motivation, student attitude, and self-efficacy. Cooperative and collaborative group sizes strategies could also be compared to determine their impact on learning outcomes in project-based learning environments. The cognitive style of field-dependent or field-independent, for instance, may be examined to explore the impact of collaborative or cooperative group sizes on learners with different cognitive styles in project-based learning environments.

\section{$7 \quad$ Acknowledgement}

The authors acknowledge the Deanship of Scientific Research at King Faisal University for the financial support under Nasher Track (Grant No. 186099).

\section{$8 \quad$ References}

[1] Abdelsameea, H. M. A. (2015). The effectiveness of collaborative group size of electronic brainstorming on the development of students' thinking skills in the Educational Technology Department. Studies in University Education, 30, 551-593.

[2] AbuSeileek, A. F. (2012). The effect of computer-assisted cooperative learning methods and group size on the EFL learners' achievement in communication skills. Computers \& Education, 58(1), 231-239. https://doi.org/10.1016/j.compedu.2011.07.011

[3] Afify, M. K. (2019). The influence of group size in the asynchronous online discussions on the development of critical thinking skills, and on improving students' performance in online discussion forum. International Journal of Emerging Technologies in Learning, 14(5), 132-219. https://doi.org/10.3991/ijet.v14i05.9351 
[4] Akcaoglu, M. \& Lee, E. (2016). Increasing social presence in online learning through small group discussions. The international review of research in open and distributed learning, 17(3), 1-17. https://doi.org/10.19173/irrodl.v17i3.2293

[5] Amamou, S. \& Cheniti-Belcadhi, L. (2018). Tutoring in project-based learning. Procedia Computer Science, 126, 176-185. https://doi.org/10.1016/j.procs.2018.07.221

[6] Ayan, M. (2012). The influence of project based learning on elementary school students' academic achievement in science education. Journal of Turkish Educational Sciences, 10(1), 167-183.

[7] Baş, G. (2011). Investigating the effects of project-based learning on students' academic achievement and attitudes towards English lesson. The Online Journal of New Horizons in Education, 1(4), 1-15.

[8] Baser, D., Ozden, M. Y., \& Karaarslan, H. (2017). Collaborative project-based learning: An integrative science and technological education project. Research in Science \& Technological Education, 35(2), 131-148. https://doi.org/10.1080/02635143.2016.12747 $\underline{23}$

[9] Biasutti, M. \& El-Deghaidy, H. (2015). Interdisciplinary project-based learning: an online wiki experience in teacher education. Technology, Pedagogy and Education, 24(3), 339355. https://doi.org/10.1080/1475939x.2014.899510

[10] Bilgin, I., Karakuyu, Y., \& Ay, Y. (2015). The effects of project based learning on undergraduate students' achievement and self-efficacy beliefs towards science teaching. Eurasia Journal of Mathematics, Science \& Technology Education, 11(3), 469-477. https ://doi.org/10.12973/eurasia.2014.1015a

[11] Blatchford, P., \& Russell, A. (2019). Class size, grouping practices and classroom management. International Journal of Educational Research 96, 154-163. https://doi.org/ $\underline{10.1016 / j . i j e r .2018 .09 .004}$

[12] Brame, C. J. \& Biel, R. (2015). Setting up and facilitating group work: Using cooperative learning groups effectively. Retrieved from http://cft.vanderbilt.edu/guides-sub-pages/sett ing-up-and-facilitating-group-work-using-cooperative-learning-groups-effectively/

[13] Branch, B. M. (2009). Instructional design: The ADDIE approach. New York: Springer.

[14] Bristol, T. J. \& Kyarsgaard, V. (2012). Asynchronous discussion: A comparison of larger and smaller discussion group size. Nursing Education Perspectives, 33(6), 386-390. https $: / /$ doi.org/10.5480/1536-5026-33.6.386

[15] Chang, C. C. \& Tseng, K. H. (2011). Using a web-based portfolio assessment system to elevate project-based learning performances. Interactive Learning Environments, 19(3), 211-230. https://doi.org/10.1080/10494820902809063

[16] Chatwattana, P., \& Nilsook, P. (2017). A Web-based Learning System using Project-based Learning and Imagineering. International Journal of Emerging Technologies in Learning, 12(5), 4-22. https://doi.org/10.3991/ijet.v12i05.6344

[17] Chen, C. H. \& Yang, Y. C. (2019). Revisiting the effects of project-based learning on students' academic achievement: A meta-analysis investigating moderators. Educational Research Review, 26, 71-81. https://doi.org/10.1016/i.edurev.2018.11.001

[18] Chou, P. N. \& Chang, C. C. (2018). Small or large? The effect of group size on engineering students' learning satisfaction in project design courses EURASIA Journal of Mathematics, Science and Technology Education, 14(10), 1-9. https://doi.org/10.29333/ej $\underline{\text { mste } / 93400}$

[19] Ciftci, S. (2015). The effects of using project-based learning in social studies education to students' attitudes towards social studies courses. Procedia-Social and Behavioral Sciences, 186, 1019-1024. https://doi.org/10.1016/j.sbspro.2015.04.205 
[20] Coskun, H. (2011). The effects of group size, memory instruction, and session length on the creative performance in electronic brainstorming groups. Educational Sciences: Theory and Practice, 11(1), 91-95.

[21] Curşeu, P. L., Schruijer, S. G., \& Fodor, O. C. (2017). Minority dissent and social acceptance in collaborative learning groups. Frontiers in Psychology, 8(458), 1-9. https:// doi.org/10.3389/fpsyg.2017.00458

[22] Deutsch, M. (1949). A theory of cooperation and competition. Human Relations, 2, 129 152.

[23] El-Said, N. \& El-Emam Rabea, A. (2017). The effect of the groups size difference in casebased elearning via Internet on developing analytical thinking skills and quality electronic kits production quality in educational technology female students and their acceptance of such difference and their responses to group size. Arabic Studies in Education and Psychology (ASEP), (86), Part 2.

[24] English, M. C. \& Kitsantas, A. (2013). Supporting student self-regulated learning in problem- and project-based learning. Interdisciplinary Journal of Problem-Based Learning, 7(2). https://doi.org/10.7771/1541-5015.1339 Article 6 https://doi.org/10.7771/ $\underline{1541-5015.1339}$

[25] Enu, J., Danso, P. A., \& Awortwe, P. K. (2015). Effects of group size on students' mathematics achievement in small group settings. Journal of Education and Practice, 6(1), $119-122$.

[26] Han, S., Capraro, R., \& Capraro, M. M. (2015). How science, technology, engineering, and mathematics (STEM) project-based learning (PBL) affects high, middle, and low achievers differently: The impact of student factors on achievement. International Journal of Science and Mathematics Education, 13(5), 1089-1113. https://doi.org/10.1007/s10763-014-9526$\underline{0}$

[27] Hixson, N. K., Ravitz, J., \& Whisman, A. (2012). Extended professional development in project-based learning: Impacts on 21st century teaching and student achievement. Charleston, WV: West Virginia Department of Education, Division of Teaching and Learning, Office of Research.

[28] Holmes, V.-L. \& Hwang, Y. (2016). Exploring the effects of project-based learning in secondary mathematics education. The Journal of Educational Research, 109(5), 449-463. https://doi.org/10.1080/00220671.2014.979911

[29] Hugerat, M. (2016). How teaching science using project-based learning strategies affects the classroom-learning environment. Learning Environments Research, 19(3), 383-395. https://doi.org/10.1007/s10984-016-9212-y

[30] Ismaeel, D. A. \& Al Mulhim, E. N. (2019). Impact of e-learning strategies to design eportfolio on achievement motivation and product quality. International Journal of Distance Education Technologies (IJDET), 17(2), 59-73. https://doi.org/10.4018/ijdet. 2019040104

[31] Iwamoto, D. H., Hargis, J., \& Vuong, K. (2016). The effect of project-based learning on student performance: An action research study. International Journal for the Scholarship of Technology Enhanced Learning, 1(1), 24-42.

[32] Johnson, D. R., Renzulli, L., Bunch, J., \& Paino, M. (2013). Everyday observations developing a sociological perspective through a portfolio term project. Teaching Sociology, 41(3), 314-321. https://doi.org/10.1177/0092055X13480642

[33] Johnson, D. W., \& Johnson, R. T. (2008). Social interdependence theory and cooperative learning: The teacher's role. In The teacher's role in implementing cooperative learning in the classroom (pp. 9-37). Springer, Boston, MA. https://doi.org/10.1007/978-0-387-70892$\underline{8} 1$ 
[34] Kanter, D. E. \& Konstantopoulos, S. (2010). The impact of a project-based science curriculum on minority student achievement, attitudes, and careers: the effects of teacher content and pedagogical content knowledge and inquiry-based practices. Science Education. 94(5), 855-887. https://doi.org/10.1002/sce.20391

[35] Khong, J. Z., Liem, G. A. D., \& Klassen, R. M. (2017). Task performance in small group settings: The role of group members' self-efficacy and collective efficacy and group's characteristics. Educational Psychology, 37(9), 1082-1105. https://doi.org/10.1080/014434 $\underline{10.2017 .1342767}$

[36] Kim, J. (2013). Influence of group size on students' participation in online discussion forums. Computers \& Education, 62, 123-129. https://doi.org/ 10.1016/j.compedu.2012. $\underline{10.025}$

[37] Kooloos, J. G., Klaassen, T., Vereijken, M., Van Kuppeveld, S., Bolhuis, S., \& Vorstenbosch, M. (2011). Collaborative group work: Effects of group size and assignment structure on learning gain, student satisfaction and perceived participation. Medical Teacher, 33(12), 983-988. https://doi.org/10.3109/0142159x.2011.588733

[38] Larson, J. R. (2009). In Search of Synergy in Small Group Performance. New York, NY: Psychology Press.

[39] Lee, H. J., \& Lim, C. (2012). Peer evaluation in blended team project-based learning: What do students find important? Journal of Educational Technology \& Society, 15(4), 214-224.

[40] Lewin, K. (1935). A dynamic theory of personality. New York: McGraw-Hill.

[41] Lin, J. W. \& Tsai, C. W. (2016). The impact of an online project-based learning environment with group awareness support on students with different self-regulation levels: An extended-period experiment. Computers \& Education, 99, 28-38. https://doi. org/10.1016/j.compedu.2016.04.005

[42] Mahasneh, A. M. \& Alwan, A. F. (2018). The effect of project-based learning on student teacher self-efficacy and achievement. International Journal of Instruction, 11(3), 511524. https://doi.org/10.12973/iji.2018.11335a

[43] Manathunga, K. \& Hernández-Leo, D. (2015). Has research on collaborative learning technologies addressed massiveness? A literature review Journal of Educational Technology \& Society, 18(4), 357-370.

[44] Melero, J., Hernández-Leo, D., \& Manatunga, K. (2015). Group-based mobile learning: Do group size and sharing mobile devices matter? Computers in Human Behavior, 44, 377-385. https://doi.org/10.1016/j.chb.2014.11.078

[45] Panadero, E. \& Järvelä, S. (2015). Socially shared regulation of learning: A review. European Psychologist, 20(3), 190-203. https://doi.org/10.1027/1016-9040/a000226

[46] Parks-Stamm, E. J., Zafonte, M., \& Palenque, S. M. (2017). The effects of instructor participation and class size on student participation in an online class discussion forum. British Journal of Educational Technology, 48(6), 1250-1259. https://doi.org/ $10.1111 /$ bjet.12512

[47] Paschalis, G. (2017). A compound LAMS-MOODLE environment to support collaborative project-based learning: A case study with the group investigation method. Turkish Online Journal of Distance Education, 18(2), 134-150. https://doi.org/10.17718/tojde.306565

[48] Paulus, P. B., Kohn, N. W., Arditti, L. E., \& Korde, R. M. (2013). Understanding the group size effect in electronic brainstorming. Small Group Research, 44(3), 332-352. https ://doi.org/10.1177/1046496413479674

[49] Qin, L. (2017). Design and realization of project-based computer English learning system. International Journal of Emerging Technologies in Learning (iJET), 12(8), 128136. https://doi.org/10.3991/ijet.v12i08.7147 
[50] Revelle, K. Z. (2019). Teacher perceptions of a project-based approach to social studies and literacy instruction. Teaching and Teacher Education, 84, 95-105. https://doi.org/ $\underline{10.1016 / j . t a t e .2019 .04 .016}$

[51] Rogers, M. A. P., Cross, D. I., Gresalfi, M. S., Trauth-Nare, A. E., \& Buck, G. A. (2011). First year implementation of a project-based learning approach: The need for addressing teachers' orientations in the era of reform. International Journal of Science and Mathematics Education, 9(4), 893-917. https://doi.org/10.1007/ s10763-010-9248-x

[52] Seman, L. O., Hausmann, R., \& Bezerra, E. A. (2018). On the students' perceptions of the knowledge formation when submitted to a project-based learning environment using web applications. Computers \& Education, 117, 16-30. https://doi.org/10.1016/j.compedu.20 $\underline{17.10 .001}$

[53] Shaw, R. S. (2013). The relationships among group size, participation, and performance of programming language learning supported with online forums. Computers \& Education, 62, 196-207. https://doi.org/10.1016/j.compedu.2012. 11.001

[54] Shih, J. L., Chuang, C. W., \& Hwang, G. J. (2010). An inquiry-based mobile learning approach to enhancing social science learning effectiveness. Educational Technology \& Society, 13(4), 50-62.

[55] Splichal, J. M., Oshima, J., \& Oshima, R. (2018). Regulation of collaboration in projectbased learning mediated by CSCL scripting reflection. Computers \& Education, 125, 132 145. https://doi.org/10.1016/j.compedu.2018.06.003

[56] Summers, E. J. \& Dickinson, G. (2012). A longitudinal investigation of project-based instruction and student achievement in high school social studies. Interdisciplinary Journal of Problem-Based Learning, 6(1), 82-103. https://doi.org/10.7771/1541-5015.1313

[57] Sung, Y. T., Yang, J. M., \& Lee, H. Y. (2017). The effects of mobile-computer-supported collaborative learning: Meta-analysis and critical synthesis. Review of Educational Research, 87(4), 768-805. https://doi.org/10.3102/0034654317704307

[58] Susanti, J., Susilowibowo, H., \& Hardini, T. (2019), Effectiveness of project-based learning models to improve learning outcomes and learning activities of students in innovative learning. In International Conference on Economics, Education, Business and Accounting, KnE Social Sciences, 82-95. https://doi.org/10.18502/kss.v3i11.4000

[59] Tabuk, M. \& Ozdemir, Ş. A. (2009). The effects of multiple intelligence approach in project based learning on mathematics achievement. International Online Journal of Educational Sciences, 1 (1), 177-195.

\section{Authors}

Ensaf Nasser Al Mulhim had her PhD of e-learning and training from the University of Plymouth in the UK in 2014. She had her Master degree in ICT in Education and Training in 2008 from the University of Wollongong, Australia. She is now an Assistant Professor at the Educational Technology Department, Faculty of Education at King Faisal University in Saudi Arabia. She worked as Vice-Dean of the King Faisal University Center for Communications and Media in 2016/2017. She also was the head of the Alumni Committee at the Faculty of Education for two years 2015/2017. And the head of the Final Exams Control in 2018/2019 at the Faculty of Education. She is an active researcher in the field of e-learning and her areas of interest are e-learning and training, online learning, blended learning, Web 2.0 evaluation tools, learning styles, professional development. 
Amany Ahmed Eldokhny, $\mathrm{PhD}$ (Ain Shams University), is an Egyptian Associate Professor. She works at the Educational Technology Department, Faculty of Education at King Faisal University in Saudi Arabia. Her interests lie at the intersection of instruction, technology and sociology. She has participated in various international academic projects. She has 14 years of experience with Saudi and Egyptian teaching settings. aeldokny@,kfu.edu.sa

Article submitted 2019-12-28. Resubmitted 2020-02-24. Final acceptance 2020-02-26. Final version published as submitted by the authors. 